Portland State University

PDXScholar

1978

\title{
Purification and characterization of NADH oxidase and peroxidase from Lactobacillus casei
}

Louise Ann Barstad

Portland State University

Follow this and additional works at: https://pdxscholar.library.pdx.edu/open_access_etds

Part of the Chemistry Commons

Let us know how access to this document benefits you.

\section{Recommended Citation}

Barstad, Louise Ann, "Purification and characterization of NADH oxidase and peroxidase from Lactobacillus casei" (1978). Dissertations and Theses. Paper 2790.

https://doi.org/10.15760/etd.2785

This Thesis is brought to you for free and open access. It has been accepted for inclusion in Dissertations and Theses by an authorized administrator of PDXScholar. Please contact us if we can make this document more accessible: pdxscholar@pdx.edu. 
AN ABSTRACT OF THE THESIS OF Louise Ann Barstad for the Master of Science in Chemistry presented November 9, 1978.

Title: Purification and Characterization of NADH Oxidase and Peroxidase from Lactobacillus casei.

APPROVED BY MEMBERS OF THE THESIS COMMITTEE:

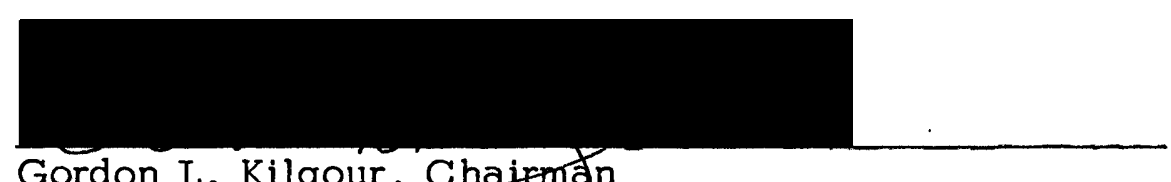

Gordon L. Kilgour, Chairmon
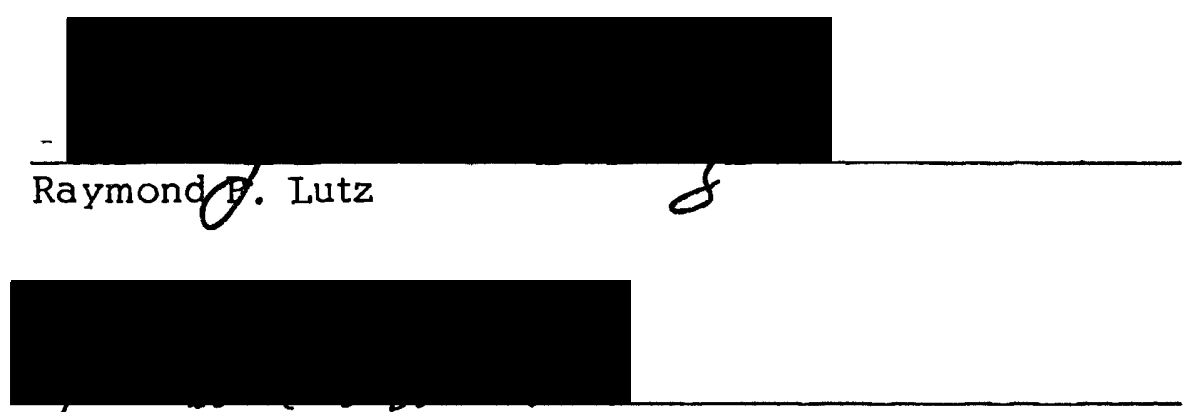

Horace F. White

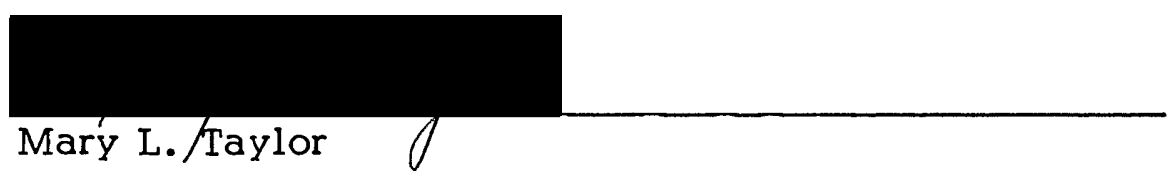

A protein exhibiting NADH oxidase and NADH peroxidase activity has been isolated from Lactobacillus casei in high purity. Evidence obtained through gel filtration, electrophoresis, and electrofocusing indicates that the two activities are characteristic of a single tetrameric protein with an approximate molecular weight of 240,000 . 


\title{
PURIFICATION AND CHARACTERIZATION OF NADH OXIDASE AND PEROXIDASE FROM LACTOBACILLUS CASEI
}

\author{
by \\ LOUISE ANN BARSTAD
}

A thesis submitted in partial fulfillment of the requirements for the degree of

\author{
MASTER OF SCIENCE \\ in \\ CHEMISTRY
}

Portland State University

1979 
TO THE OFFICE OF GRADUATE STUDIES AND RESEARCH:

The members of the Committee approve the thesis of Louise Ann Barstad presented November 9, 1978.
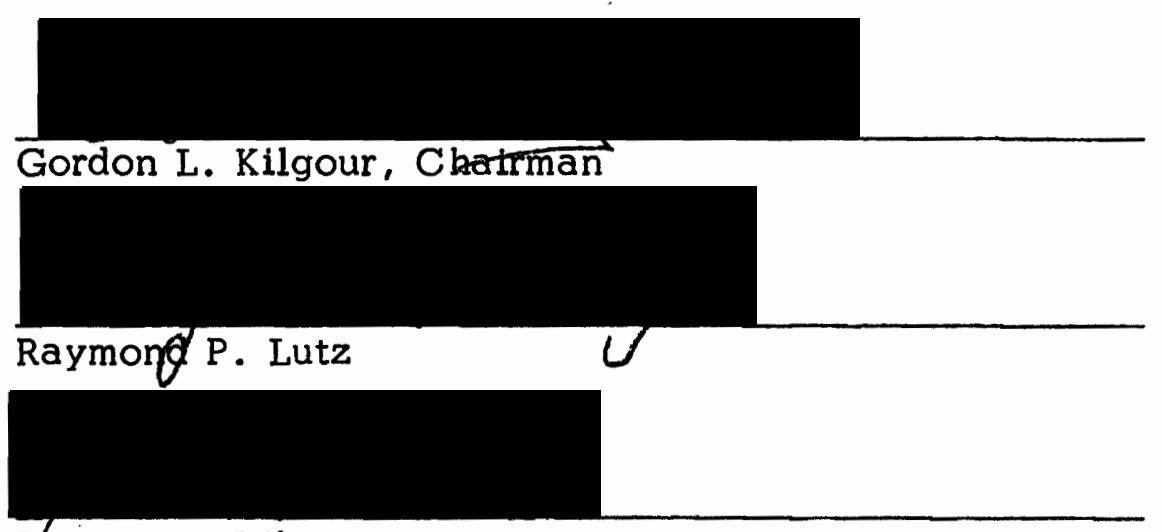

Horace F. White

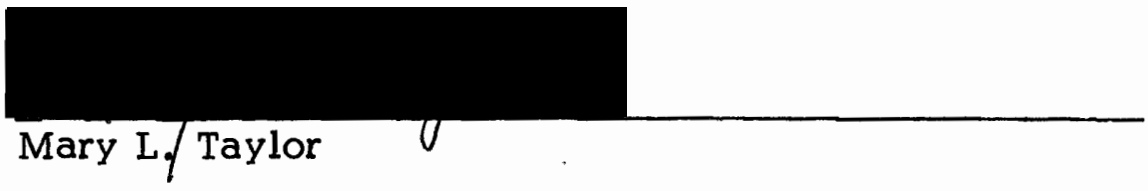

\section{APPROVED:}

David W. McClure, Head, Department of Chemistry

Stanley E. Rauch, Dean of Graduate Studies and Research 


\section{ACKNOWLEDGEMENTS}

Special thanks are offered to $\mathrm{Dr}$. Gordon L. Kilgour for his unfailing patience and concern, to Drs. Joann S. Loehr and Mary L. Taylor for their encouragement and the occasional use of their equipment and chemicals, to Dr. Gary L. Gard for encouraging me to try graduate work in the first place, to my parents for making it impossible to quit, and to my husband Bill for enduring the whole thing. 
TABLE OF CONTENTS

PAGE

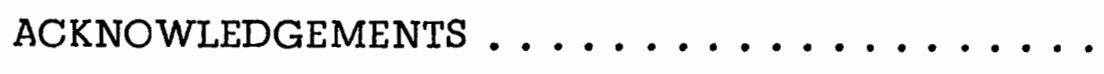

LIST OF TABLES . . . . . . . . . . . . .

LIST OF FIGURES . . . . . . . . . . . .

$\mathrm{v}$

vi

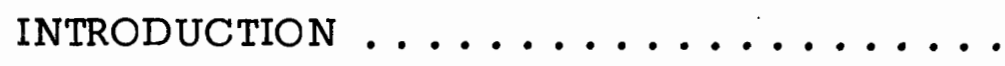

1

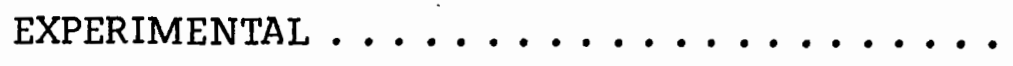

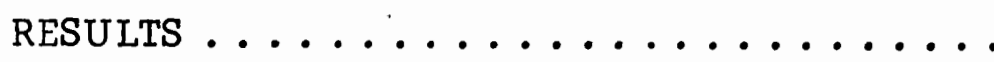

13

DISCUSSION

REFERENCES. 


\section{LIST OF TABLES}

T A B L E

PAGE

Purification of NADH Peroxidase from $\underline{L}$. casei 18

II Purification of NADH Oxidase from $\underline{L}$. casei 
LIST OF FIGURES

FIGURE

PAGE

1

Gradient Elution Apparatus .........

2 Typical Separation Obtained with DEAEcellulose...............

Typical Separation Obtained with Sephadex

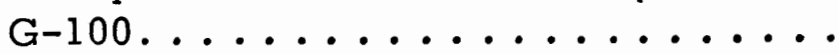

Typical Separation Obtained with Sephacryl

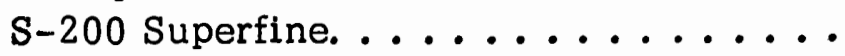

Typical Separation Obtained with Sephadex

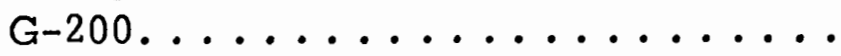

6 Determination of Subunit Molecular Weight by SDS-polyacrylamide Gel Electrophoresis.

Ultraviolet Light Absorption Spectrum of Enzyme in Peak Fraction after the Final Purification

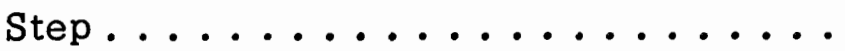

8 Visible Light Spectrum of Enzyme in Peak Fraction after the Final Purification Step ..... 26

9 Five per Cent Polyacrylamide Disc Gel Electro-

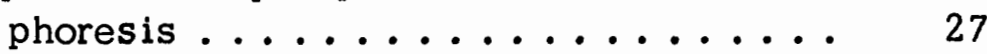

11 Relative Activity vs. $\mathrm{pH}$ for Oxidase and Per-

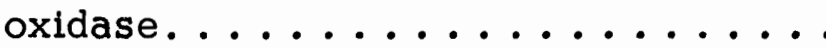




\section{INTRODUCTION}

Lactobacillus casei is an oxygen-tolerant anaerobic bacterium. Like others of its kind, it is capable of eliminating molecular oxygen and the product of its reduction, hydrogen peroxide; without allowing damage to cell components. Reduced nicotinamide adenine dinucleotide (NADH) oxidase and NADH peroxidase provide a mechanism for the removal of molecular oxygen and hydrogen peroxide by the following reactions (1):

NADH oxidase: $\mathrm{NADH}+\mathrm{H}^{+}+\mathrm{O}_{2} \longrightarrow \mathrm{H}_{2} \mathrm{O}_{2}+\mathrm{NAD}^{+}$

$\mathrm{NADH}$ peroxidase: $\mathrm{NADH}+\mathrm{H}^{+}+\mathrm{H}_{2} \mathrm{O}_{2} \longrightarrow 2 \mathrm{H}_{2} \mathrm{O}+\mathrm{NAD}^{+}$

Molecular oxygen may not be toxic. However, it is quickly reduced to hydrogen peroxide by flavoproteins found in all organisms. Hydrogen peroxide is so destructive to cell components that all airtolerant organisms, aerobic or anaerobic, are thought to possess an enzyme capable of removing it. In aerobic organisms, the peroxideeliminating enzyme is catalase, a heme-containing protein which catalyzes the auto-oxidation-reduction of hydrogen peroxide to water and molecular oxygen. The oxygen can eventually be reduced to water without the formation of hydrogen peroxide. Catalase activity would not be useful to an anaerobic organism, since it cannot use molecular oxygen without the formation of hydrogen peroxide. An added problem is that most anaerobes do not possess the genetic information necessary for the production of the heme, the prosthetic group responsible for catalase activity. The lactic acid bacterla circumvent the problem by producing NADH peroxidase, which reduces hydrogen peroxide to water. The peroxidase is unusual in that it is a flavoprotein instead of a heme-protein, as are hydrogen peroxide-reducing enzymes found in a erobes. 
Historical

Flavoproteins with NADH oxidase and NADH peroxidase activities were first isolated from the air-tolerant anaerobe Streptococcus faecalis in 1953 by M.I. Dolin (1). The oxidase was easily separated from the peroxidase by ammonium sulfate precipitation, and little further work was done with it. The peroxidase was made commercially available as a solution with a concentration of one milligram per milliliter by Boehringer-Mannheim Biochemicals, Indianapolis, in April, 1977 (2).

Since 1953 similar enzymes have been found in other air-tolerant anaerobes (3). In $1959 \mathrm{NADH}$ oxidase and NADH peroxidase were found in Lactobacillus casei, the standard riboflavin assay organism, by Strittmatter (4). A partial purification of the enzymes was achieved at that time by precipitation in $75 \%$ saturated ammonium sulfate. The resulting precipitate accounted for about $30 \%$ of the total soluble protein and $65 \%$ of the total flavoprotein produced by $\underline{\text {. Casei, and }}$ most of the flavin present was flavin adenine dinucleotide (FAD). Included in this precipitate was a protein capable of oxidizing NADH while reducing ferricyanide ion. Its function is still unknown. In 1965 Walker and Kilgour, referring to the ferricyanide-reducing enzyme as a "diaphorase," found that it contained flavin mononucleotide (FMN), and not FAD (5). It was readily separated from $\mathrm{NADH}$ oxidase and NADH peroxidase by gel filtration.

Attempts were made to separate the NADH oxidase from the NADH peroxidase by various methods including ammonium sulfate precipitation, gel filtration, Ion exchange chromatography, and starch block gel electrophoresis (6). None of these attempts were successful, and it was suggested that NADH oxidase and NADH peroxidase might be different activities of a single enzyme (7).

This report will show a purification method for NADH oxidase and NADH peroxidase which is simpler and which produces enzyme of greater purity than that achieved by Walker and Kilgour. In addition, characterization of the enzyme given in this report implies that, indeed, 
NADH oxidase and NADH peroxidase are activities belonging to a single enzyme. Before proceding further, however, it is necessary to mention those properties which have already been reported for NADH oxidase and NADH peroxidase found in $\underline{\mathrm{L}}$. casei.

\section{NADH oxidase}

Strittmatter found that NADH oxidase has a specific requirement for FAD, but not for FMN or riboflavin (4). The presence of $10^{-5}$ molar FAD causes as much as a fifty-fold increase in activity. Walker and Kilgour have shown that activity lost during the purification of the enzyme could be restored by incubation with cysteine and FAD (6). Past inhibition studies involving sulfhydryl group binding agents such as $\mathrm{p}$-hydroxymercuribenzoate or $\mathrm{N}$-ethylmaleimide are not reliable, nor are inhibition studies involving metal chelating agents. The presence of manganous ion appears to increase oxidase activity (4).

While NADH appears to be the only acceptable electron donor, methylene blue is also a suitable electron acceptor for $\mathrm{NADH}$ oxidase. In fact, the enzyme will catalyze the reduction of methylene blue without the addition of FAD. It should be noted that the "methylene blue reductase" activity of the enzyme is defined as an oxidase activity, since methylene blue is auto-oxidizable (8).

\section{NADH peroxidase}

It has been shown (6) that the natural flavin cofactor in NADH peroxidase is FAD. The enzyme is very specific for NADH as an electron donor. Slight activity may be observed when ferricyanide is the electron acceptor, but other substances tested (various quinones and cytochrome c) are not suitable substrates. The enzyme appears to be inhibited by sulfhydryl group binding agents, but not by metal chelating agents . 


\section{EXPERIMENTAL}

\section{Instrumentation}

All determinations of protein concentration and all enzyme assays were done with a Beckman DU Spectrophotometer equipped with a Gilford Model 2000 Multiple Sample Recorder. Absorbance spectra were obtained with a Cary Model 14 Recording Spectrophotometer. A Radiometer $\mathrm{pH}$ Meter 26 was used for all measurements of $\mathrm{pH}$.

\section{Enzyme assay procedure}

The standard enzyme assay procedures used are those of Walker and Kilgour (5) .

For the standard NADH oxidase assay, the following were placed in a $1.5 \mathrm{ml}$. silica cell of $1.0 \mathrm{~cm}$. pathlength: $0.10 \mathrm{ml}$. of enzyme, $0.40 \mathrm{ml}$. of $0.10 \mathrm{M}$ potassium phosphate buffer at $\mathrm{pH} 7.0,0.30 \mathrm{ml}$. of distilled water, and $0.10 \mathrm{ml}$. of $1.08 \times 10^{-4} \mathrm{M}$ FAD. The reaction was started by the addition of $0.10 \mathrm{ml}$. of $0.01 \mathrm{M}$ potassium phosphate buffer containing $\mathrm{NADH} .(\mathrm{lg} . / \mathrm{ml}$.$) at \mathrm{pH} 7.45$. Oxidation of the NADH was followed spectrophotometrically by recording the decrease with time of the absorbance at $340 \mathrm{~nm}$.

For the standard NADH peroxidase activity assay, the following were placed in a $1.5 \mathrm{ml}$. silica cell of $1.0 \mathrm{~cm}$. pathlength: $0.10 \mathrm{ml}$. of enzyme, $0.40 \mathrm{ml}$. of $0.10 \mathrm{M}$ sodium acetate buffer at $\mathrm{pH} 5.4,0.30 \mathrm{ml}$. of distilled water, and $0.10 \mathrm{ml}$. of $0.03 \%$ hydrogen peroxide solution. The reaction was started, as above, with the addition of NADH.

When methylene blue reductase activity was measured, the standard oxidase assay was used with the substitution of $0.10 \mathrm{ml}$. of $1 \times 10^{-5} \mathrm{M}$ methylene blue instead of FAD.

For the determination of the optimum $\mathrm{pH}$ for either oxidase or peroxidase activity, the following buffers wer substituted in the above assay procedures: 

$\underline{\mathrm{pH}}$
BUFFER
$3.6-5.6$
$0.10 \mathrm{M}$ sodium acetate
$5.5-7.0$
$0.10 \mathrm{M}$ potassium 2[N-morpholino]ethane sulfonate
$6.8-7.8$
$0.10 \mathrm{M}$ potassium morpholinopropane sulfonate

\section{Materials}

Materials were obtained from the following sources: acetic acid, ammonium hydroxide, dextrose, cupric sulfate pentahydrate, hydrochloric acid, isopropanol, dibasic potassium phosphate trihydrate, monobasic potassium phosphate, sodium acetate trihydrate, sodium carbonate, sodium hydroxide, sucrose, sulfuric acid, Malinkrodt Chemical Works; reduced disodium $\boldsymbol{\beta}$-nicotinamide adenine dinucleotide (NADH, preweighed $10 \mathrm{mg}$. vials), disodium flavin adenine dinucleotide (FAD), methylene blue, potassium 2[N-morpholino]ethane sulfonate (MES), potassium morpholinopropane sulfonate (MOPS), potassium $\mathrm{N}-2$-hydroxyethylpiperazine-N'-2-ethane sulfonate (HEPES), DEAE-cellulose, streptomycin sulfate, $\boldsymbol{\beta}$-nicotinamide adenine dinucleotide (NAD), tris (hydroxymethyl)aminomethane (Tris), flavin mononucleotide (FMN), Sigma Chemical Company; phenol reagent, Fisher Scientific Company; sodium potassium tartarate tetrahydrate (Rochelle salt), potassium hydroxide, ammonium persulfate, Matheson, Coleman, and Bell; enzyme grade ammonium sulfate, N, N, N', N'-tetramethylethylenediamine (TEMED), Mann Research Laboratories; acrylamide, N, N'-methylene bisacrylamide, Eastman Organic Chemicals; coomassie brilliant blue R-250, Bio-Rad Laboratories; Sephadex G-100, Sephadex G-200, Sephacryl S-200, superfine, Blue Sepharose CL-6B, Pharmacia Fine Chemicals; Bacto-Tryptone, Bacto-yeast extract, Difco Laboratories.

\section{Chemical determinations}

Protein concentrations were determined after each purification step using the method of Lowry, et al. (9) When ion exchange chromato- 
graphy or gel filtration was used as a purification step, the relative protein concentrations were determined by measuring the absorbance at $280 \mathrm{~nm}$. for each fraction. Cnocentration of FAD and NADH were measured spectrophotometrically using $11.3 \times 10^{3} \mathrm{~cm}^{-1}$ molar $^{-1}$ for the molar absorbance of FAD at $450 \mathrm{~nm}$. and $6.22 \times 10^{3} \mathrm{~cm} \cdot{ }^{-1} \mathrm{molar}^{-1}$ for the molar absorbance of NADH at $340 \mathrm{~nm}$. (5)

\section{Growth of Lactobacillus casei}

L. casei ATCC 7469 were grown at $30^{\circ} \mathrm{C}$. in sterile medium containing the following: $0.5 \%$ Bacto-Tryptone, $1.5 \%$ yeast extract, $0.2 \%$ $\mathrm{K}_{2} \mathrm{HPO}_{4} \cdot 3 \mathrm{H}_{2} \mathrm{O}$, and $2.0 \%$ dextrose. A dextrose solution was autoclaved separately and then added to make the final concentration of $2.0 \%$ dextrose.

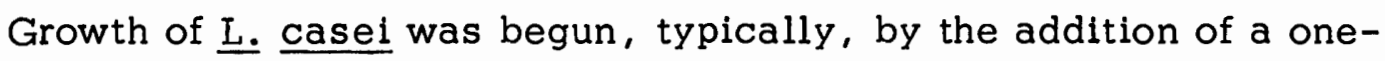
milliliter aliquot of a soft agar culture of the organism (provided by Dr. Mary Taylor) to each of two ten-milliliter tubes of the above medium. After one hour, the contents of each tube were transferred aseptically (as were all transfers) to separate flasks, each containing $100 \mathrm{ml}$. of medium. After the contents of the two flasks became turbid, about three hours, the contents of the two flasks were transferred to a single flask containing $500 \mathrm{ml}$. of medium. After about six hours the $500 \mathrm{ml}$. culture was transferred to a carboy containing ten liters of medium. The carboy was then left at $30^{\circ} \mathrm{C}$. for twelve hours after which time a ten-milliliter sample was withdrawn hourly, and the $\mathrm{pH}$ of the medium was measured. When the $\mathrm{pH}$ of the culture reached 3.7, the cells were harvested using a Sorvall RC2-B centrifuge equipped with a Szent-Gyorgyi and Blum type continuous-flow apparatus. Typically about thirty grams of cells were rinsed with distilled water and stored frozen.

\section{Cell rupture}

Frozen cells were prepared for breakage by allowing them to thaw at room temperature. A $30 \%$ suspension of the wet cells was prepared with a $0.05 \mathrm{M}$ potassium puosphate buffer at $\mathrm{pH} 7.0$. The suspension 
was passed through a French Pressure Cell (American Instrument Co., Inc.) at 9,000 p.s.1. and into an ice bath. In order to insure that a high percentage of cells would be broken, it was necessary to pass the suspension through the pressure cell four times. The resulting mixture was spun at $43,000 \times G$, and about $90 \mathrm{ml}$. of clear orange supernatant was removed. The supernatant, and any other solutions containing the enzymes sought, were kept away from direct light and at $5^{\circ} \mathrm{C}$. during all later work.

\section{Ion exchange chromatography}

DEAE-cellulose was prepared using a modification of the method described by Himmelhoch (10). Ten grams of DEAE-cellulose were added to $500 \mathrm{ml}$. of $1.0 \mathrm{M} \mathrm{KOH}$ and allowed to swell. After thirty minutes the slurry was filtered in a scintered glass funnel and washed with $500 \mathrm{ml}$. each of distilled water, $1.0 \mathrm{M} \mathrm{HCl}$, distilled water, and $1.0 \mathrm{M}$ $\mathrm{KOH}$. The filtrate was equilibrated in $0.05 \mathrm{M}$ potassium phosphate buffer at pH 6.8. A slurry of the equilibrated DEAE-cellulose was packed into a column of $1.5 \mathrm{~cm}$. diameter to a height of $20 \mathrm{~cm}$. Any surplus ion exchange medium was refrigerated for later use. A $20 \mathrm{~cm}$. column contained 3.2 grams of DEAE-cellulose and had a capacity of 3.2 milliequivalents .

To insure that the desired enzymes would bind to the exchange medium, it was necessary to dilute the cell free extract fourfold with $0.05 \mathrm{M}$ potassium phos phate buffer at $\mathrm{pH}$ 6.8. The diluted sample was applied to the column in an amount sufficient to produce a characteristic yellow band over the upper two thirds of the column. Typically this was achieved by the application of about $125 \mathrm{ml}$. of sample containing about 700 milligrams of protein. At this point application of sample was discontinued, and the column was eluted with $0.05 \mathrm{M}$ potassium phosphate buffer at pH 6.8 until the effluent solution became clear and the absorbance of the effluent solution was at a minimum when measured at $280 \mathrm{~nm}$. A gradient was then attached. This gradient consisted of two 


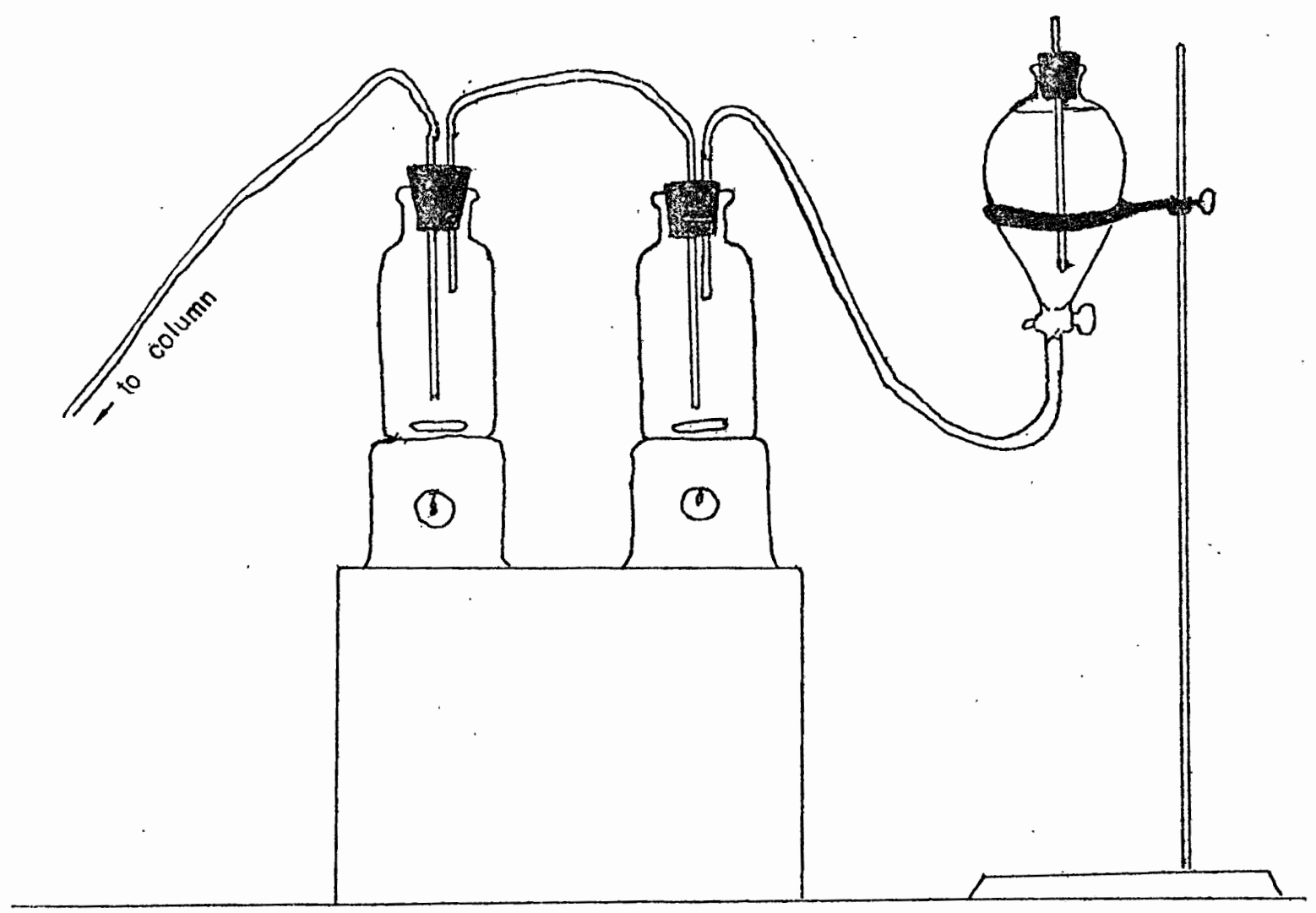

Figure 1. Gradient elution apparatus.

identical mixing tanks and a reservoir. The first tank contained $250 \mathrm{ml}$. of $0.05 \mathrm{M}$ potassium phosphate buffer at $\mathrm{pH}$ 6.8. It was followed by 250 $\mathrm{ml}$. of $0.10 \mathrm{M}$ potassium phosphate buffer at $\mathrm{pH} 7.0$ and a reservoir of 500 $\mathrm{ml}$. of $0.20 \mathrm{M}$ potassium phosphate buffer at pH 7.2 (Figure 1.). Fivemilliliter fractions were collected and assayed for protein and enzymatic activity. A typical elution pattern is shown in Figure 2.

Gel filtration with Sephadex G-100

Thirty-five grams of Sephadex G-100 were prepared in 0.05 M potassium phosphate buffer of $\mathrm{pH} 7.0$ according to the manufacturer's directions (Il) and packed into a column of $2.6 \mathrm{~cm}$. diameter. The total height of the column was $95.5 \mathrm{~cm}$.

Combined active fractions from a single DEAE-cellulose purification step containing about $150 \mathrm{mg}$. of protein were pooled and concentrated to about $7 \mathrm{ml}$. using an Amicon Ultrafiltration cell equipped with a DIAFLO 
PM10 membrane. The concentrated sample was applied to the bottom of the column through a flow adaptor and eluted by reverse flow with $0.05 \mathrm{M}$ potassium phosphate buffer of $\mathrm{pH} 7.0$. Five-milliliter fractions were collected and assayed for relative protein concentration and enzymatic activity. A typical elution pattern is shown in Figure 3.

\section{Gel filtration with Sephacryl S-200 Superfine}

Sephacryl S-200 Superfine was previously packed according to the manufacturer's directions (12) in a column of $2.5 \mathrm{~cm}$. diameter fo a final volume of $410 \mathrm{ml}$. The vold volume of the gel had been measured to be $158 \mathrm{ml}$.

The fractions demonstrating enzymatic activity were collected from a single purification step using Sephadex G-100, and concentrated to ten ml. with an Amicon Ultrafiltration Cell equipped with a DIAFLO PM10 membrane. This concentrated sample, containing about $40 \mathrm{mg}$. protein, was applied to the top of the column through a flow adaptor, and $0.05 \mathrm{M}$ potassium phosphate buffer of $\mathrm{pH} 7.0$ was used to elute the column. A Buchler Polystaltic Pump was attached to the inlet tubing, and a flow rate of $1.0 \mathrm{ml}$. per minute was maintained. Five-milliliter fractions were collected and assayed for protein concentration and enzymatic activity. A typical elution pattern is shown in Figure 4.

Other purification attempts: Precipitation of nucleic acids with streptomycin sulfate

Cell free extract was cooled to $0-2^{\circ} \mathrm{C}$. on a Thermoelectrics Stir Kool Model SK 12. 1.5 grams of streptomycin sulfate was added for each fifty milliliters of cell free extract, and the $\mathrm{pH}$ of the resulting solution was lowered to 5.0 using $4 \mathrm{~N}$ sulfuric acid. After fifteen minutes of this treatment, the solution was centrifuged at $34,800 \times G$ in a Sorvall RC2-B centrifuge for fifteen minutes. The resulting yellow supernatant solution was removed, returned to $\mathrm{pH} 7.0$ with $4 \mathrm{~N}$ ammonium hydroxide, and stored cold. A typical treatment of $71 \mathrm{ml}$. of cell free extract produced $74 \mathrm{ml}$. of supernatant. 
Fractional precipitation with ammonium sulfate

Enzyme grade ammonium sulfate was added to cell free extract to $50 \%$ saturation while stirring at $0^{\circ} \mathrm{C}$. on a Thermoelectrics Stir Kool Model SK 12. The $\mathrm{pH}$ of the resulting mixture was adjusted to 7.0 with $4 \mathrm{~N}$ ammonium hydroxide. After stirring at $0^{\circ} \mathrm{C}$. for 45 minutes, the mixture was spun in a Sorvall $\mathrm{RC} 2-\mathrm{B}$ centrifuge at $34,800 \times \mathrm{G}$ for fifteen minutes. The clear yellow supernatant was again cooled to $0^{\circ}, \mathrm{C}$, and ammonium sulfate was added with stirring to produce a $75 \%$ saturated solution. This solution was adjusted to $\mathrm{pH} 7.0$ with $4 \mathrm{~N}$ ammonium hydroxide, and, after stirring at $0^{\circ} \mathrm{C}$. for 45 minutes, the resulting mixture was centrifuged at $34,800 \times \mathrm{G}$ for fifteen minutes. Both pellets were resuspended in $0.05 \mathrm{M}$ potassium phosphate buffer at $\mathrm{pH} 7.0$ for assays.

In a typical ammonium sulfate fractionation, 22.2 grams of enzyme grade ammonium sulfate were added to $73 \mathrm{ml}$. of enzyme solution, and the $\mathrm{pH}$ was adjusted to 7.0 . After stirring at $0^{\circ} \mathrm{C}$. for 45 minutes, the mixture was centrifuged at $34,800 \times \mathrm{G}$ for fifteen minutes. The $75 \mathrm{ml}$. of supernatant were removed, and to it was added 18.8 additional grams of ammonium sulfate. After readjusting the $\mathrm{pH}$ to 7.0 and stirring the mixture for 45 minutes at $0^{\circ} \mathrm{C}$, the mixture was spun at $34,800 \times \mathrm{G}$ again for fifteen minutes. $81 \mathrm{ml}$. of supernatant were removed.

\section{Gel filtration with Sephadex G-200}

Twenty-two grams of Sephadex G-200 were prepared according to the manufacturer's directions in $0.05 \mathrm{M}$ potassium phosphate buffer of $\mathrm{pH} 7.0$. The gel was packed into a column of diameter $2.5 \mathrm{~cm}$. to a final height of $96.8 \mathrm{~cm}$. Approximately five milliliters of sample were applied to the column through a flow adaptor, and the column was eluted by reverse flow with $0.05 \mathrm{M}$ potassium phos phate buffer of $\mathrm{pH} 7.0$. Five-milliliter fractions were collected and assayed for relative protein concentration and enzymatic activity. A typical elution pattern may be seen in Figure 5 .

\section{Affinity chromatography with Blue Sepharose CL-6B}

1.75 grams of Blue Sepharose CL-6B were prepared according to the 
manufacturer's directions and packed into a column of $0.9 \mathrm{~cm}$. diameter to a height of $9.6 \mathrm{~cm}$. After elution the column with $300 \mathrm{ml}$. of distilled water, the column was equilibrated with $300 \mathrm{ml}$. of $0.10 \mathrm{M}$ potassium phosphate buffer at pH $7.02 .4 \mathrm{ml}$. of sample containing $30.6 \mathrm{mg}$. of protein and about 300 peroxidase activity units were applied to the column. The column was eluted with the following solutions:

$17 \mathrm{ml}$. of $0.10 \mathrm{M}$ potassium phosphate buffer at $\mathrm{pH} 7.0$

$21 \mathrm{ml}$. of $0.10 \mathrm{M}$ potassium phosphate buffer at $\mathrm{pH} 7.0$ containing $\mathrm{NADH}, 0.12 \mathrm{mg} . / \mathrm{ml}$.

$16 \mathrm{ml}$. of $0.10 \mathrm{M}$ sodium acetate buffer at $\mathrm{pH} 5.4$ containing $\mathrm{NADH}$, $0.11 \mathrm{mg} . / \mathrm{ml}$.

$15 \mathrm{ml}$. of $0.10 \mathrm{M}$ sodium acetate buffer at $\mathrm{pH} 5.4$ containing $10 \mathrm{milli}-$ molar NAD

$15 \mathrm{ml}$. of $0.10 \mathrm{M}$ potassium phosphate buffer at $\mathrm{pH} 7.0$ containing 10 millimolar NAD.

$1.5 \mathrm{ml}$. fractions were collected and tested for protein by the method of Lowry, et al. (7)

All of these other methods listed were found to be impractical for reasons which will be discussed later.

Polyacrylamide disc gel electrophoresis

Five per cent polyacrylamide gel was prepared by mixing the following: $1.5 \mathrm{ml}$. of $3.0 \mathrm{M}$ Tris chloride buffer which was $0.5 \%$ in TEMED at $\mathrm{pH}$ $8.8,1.0 \mathrm{ml}$. of $60 \%$ acrylamide which contained $0.6 \% \mathrm{~N}, \mathrm{~N}^{\prime}$-methylene bisacrylamide, $9.5 \mathrm{ml}$. of distilled water. All solutions had been aspirated to remove dissolved oxygen before mixing. Polymerization was begun with the addition of about 0.01 gram (a few crystals) of dry ammonium persulfate, and the mixture was quickly dispensed into glass tubes of $5 \mathrm{~mm}$. inside diameter to a height of 3.5 inches. About $5 \mathrm{~mm}$. of distilled water were carefully layered over the gels. Polymerization was completed in thirty minutes. The $2.5 \%$ polyacrylamide stacking gel was prepared by mixing the following pre-aspirated solutions: $1.25 \mathrm{ml}$. of 
$20 \%$ acrylamide which contained $2.5 \% \mathrm{~N}, \mathrm{~N}^{\prime}$-methylene bisacrylamide, $1.25 \mathrm{ml}$. of $0.50 \mathrm{M}$ Tris chloride buffer which contained 1.0\% TEMED at $\mathrm{pH}$ $6.7,5.0 \mathrm{ml}$. of $40 \%$ sucrose, $1.25 \mathrm{ml}$. of distilled water, and $1.25 \mathrm{ml}$. of FMN , $0.04 \mathrm{mg} . / \mathrm{ml}$. The $5 \%$ polyacrylamide gels were blotted dry, and stacking gel solution was applied to each tube to a height of $5 \mathrm{~mm}$. A $5 \mathrm{~mm}$. layer of distilled water was carefully layered atop each, and the gels were surrounded by a bank of fluorescent lights. Photopolymerization was completed in less than thirty minutes. A Hoefer DE 102 Polyacrylamide Gel Electrophores is Unit was equipped with six gels, and both buffer tanks were filled with $0.025 \mathrm{M}$ Tris acetate buffer at $\mathrm{pH} 8.3$. Samples, $0.10 \mathrm{ml}$., were carefully layered under the buffer onto the gels. An initial current of $2 \mathrm{~mA}$ per tube was applied to allow uniform migration of sample materials through the stacking gel over a thirty-minute period, and then a current of $4 \mathrm{~mA}$ per tube was applied for three hours.

Immediately after electrophoresis, the gels were removed and immersed in a solution of $25 \%$ isopropanol, $10 \%$ acetic acid, and $0.05 \%$ Coomassie Brilliant Blue. After twelve hours the gels were transferred to a solution containing $10 \%$ isopropanol, $10 \%$ acetic acid, and $0.005 \%$ Coomassle Brilliant Blue for elght hours. The gels were destained with repeated washings of $10 \%$ acetic acid. 


\section{RESULTS}

\section{Purification}

It was decided that the most effective means of purifying the enzyme would use DEAE-cellulose chromatography followed by gel filtration, first with Sephadex G-100, and then with Sephacryl S-200 Superfine. A summary of a typical purification by that means is given in Tables I and II. The elution patterns for this same purification are shown in Figures 2, 3, and 4.

The process used results in a sixfold purification of the peroxidase. This does no, in itself, indicate a high degree of purity, but characterization of the protein (as is discussed later in this paper) indicated that a high degree of purity actually is achieved. Ten per cent of the inital peroxidase activity is retained.

The summary of the purification is inconclusive in the case of the oxidase activities. The oxidase is known to diminish in activity over a period of time (6), and no compensation is made for loss of activity in the summary. While no comparison can be made between the activity totals for the oxidase and peroxidase activities, it can be seen in the elution patterns that there is maintained a ratio of about one unit of oxidase activity to one hundred units of peroxidase activity throughout the purification process.

Other purification methods, as mentioned, were not used because of a variety of problems. Ammonium sulfate precipitation was discontinued, because the treatment was considered to be excessively harsh. Use of ammonium sulfate caused a fifty per cent loss of peroxidase activity, and an even greater loss of oxidase activity. In addition, the use of ammonium sulfate did not make any of the three adopted purification steps unnecessary. The same problem was found to be the case with streptomycin sulfate. In addition, reproducible activities could 
not be obtained immediately after treatment with streptomycin sulfate.

In the case of affinity chromatography with Blue Sepharose CI-6B, no suitable elution system has yet been found. However, it might still be possible to devise a one-step purification process, if the correct elution system can be found.

Sephadex G-200 proved to be an excellent gel filtration medium on a small scale. Elution patterns (shown in Figure 5), which are very reproducible, were use to obtain an approximate molecular weight for the enzyme. The problem with Sephadex G-200, was that a column large enough for a full-scale purification elther took several days to elute, or it would collapse before elution could be completed.

\section{Characterization}

Elution form Sephadex G-200 was us ed to obtain an approximate molecular weight of 226,000 . A subunit analysis from polyacrylamidesodium dodecyl sulfate gel electrophoresis (kindly performed by Dr. Joann Loehr) gave an approximate subunit molecular weight of 61,000 (see Figure 6).

Ultraviolet and visible light spectra (Figures 7 and 8) were obtained with the purified enzyme, and the extinction coefficient at $280 \mathrm{~nm}$. was found to be $1.09 \mathrm{mg} .^{-1} \mathrm{~cm} .^{2}$ The results of polyacrylamide disc gel electrophoresis and gel electrofocusing (kindly done by Dr. Mary Taylor) are shown in Figure 9 and 10. 


\section{DISCUSSION}

Although a molecular weight of 226,000 is indicated by gel filtration with Sephadex G-200, this number must be assumed to be a minimum value. The elution of flavoproteins usually is retarded by dextran gels (13), and the result is an incorrectly low molecular weight. Polyacrylamide-sodium dodecyl sulfate gel electrophoresis is more reliable for molecular weight determinations, but it may be used to determine molecular weights only for covalently bound materials. From electrophoresis with sodium dodecyl sulfate, the molecular weight of all subunits was found to be 61,000 . Assuming that the molecular weight of the enzyme is at least 226,000, and that that same molecular weight is a multiple of 61,000 , one can conclude that the enzyme is a tetramer of 244,000 .

The methods described previously give only a sixfold purification, but several factors indicate that the enzyme produced is of high purity. Gel filtration with Sephacryl S-200 Superfine produced an elution pattern (see Figure 4) for which the shapes of the protein concentration and activity patterns are almost identical. Against this pattern a very low background absorbance is observed. The ultraviolet and visible light spectra are very well defined (Figure 7 and 8), and again a relatively low background absorbance is found a 310 and above $500 \mathrm{~nm}$. Polyacrylamide-sodium dodecyl sulfate gel electrophoresis produced a single band after the final purification step. Polyacrylamide disc gel electrophoresis produced two close bands of which one was of half the intensity of the other. While there is a possibility that one of these bands is an impurity, it is probable that the lighter band is due to the loss of one or more flavins.

It had been suggested that $\mathrm{NADH}$ oxidase and $\mathrm{NADH}$ peroxidase might be a single enzyme with more than one activity (7). Evidence in this paper supports that idea. Not only are the activities not separable 
with Sephacryl S-200 Superfine, but, when this medium is used, the oxidase and peroxidase activities coincide perfectly. Throughout the purification process a constant ratio was observed between oxidase and peroxidase activities. The patterns obtained with electrophoresis also suggest that this is one enzyme.

With gel electrofocusing one obtains a pattern similar to that found with polyacrylamide disc gel electrophoresis (see Figure 10). However, when $8 \mathrm{M}$ urea is used, there are even more bands. A possible explanation for this is that there are two kinds of subunits in the enzyme. One type of subunit loses its flavin easily. Its resulting isoelectric point would be higher than that of the subunit to which a flavin is tightly bound. Walker and Kilgour (6) proposed that $\mathrm{NADH}$ oxidase possesses a labile flavin group which would be easily lost through oxidation over a period of time. The peroxidase, on the other hand, is very strongly bound to its flavin group. The pattern produced in $8 \mathrm{M}$ urea, therefore, could represent various monomers, dimers, and trimers of the oxidase and peroxidase subunits with and without attached flavin nucleotides.

At this point it becomes obvious that the enzyme found in $\underline{L}$. casei

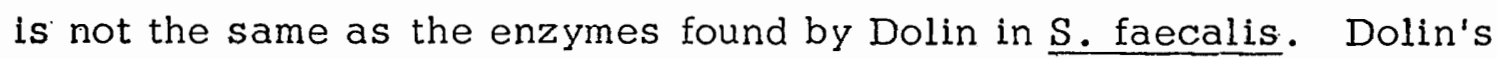
enzymes were separable (1), and the peroxidase was found to have a molecular weight of 120,000 (14), with a pH optimum of 5.4. The enzyme found in $\underline{L}$. casei has no measurable $\mathrm{pH}$ optimum (see Figure 11). However, there are some similarities that should not be overlooked. The

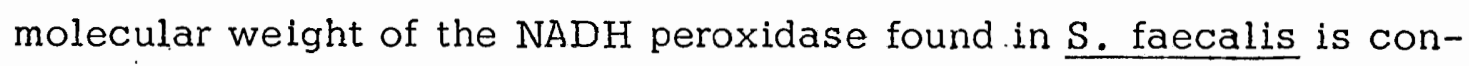
veniently twice that of the subunit of the $L$. casei enzyme, and the visible light spectrum of the $\underline{L}$. casei enzyme is almost identical to that of the

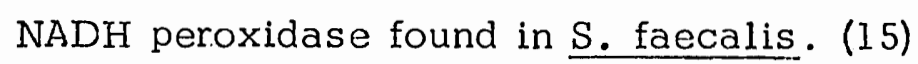

In summary, the NADH oxidase and peroxidase activities of Lactobacillus casei have been isolated in high purity. Examination of this protein complex lends strong support to the proposition that the oxidase and the peroxidase activities are associated with a single multimeric 
protein unit. 


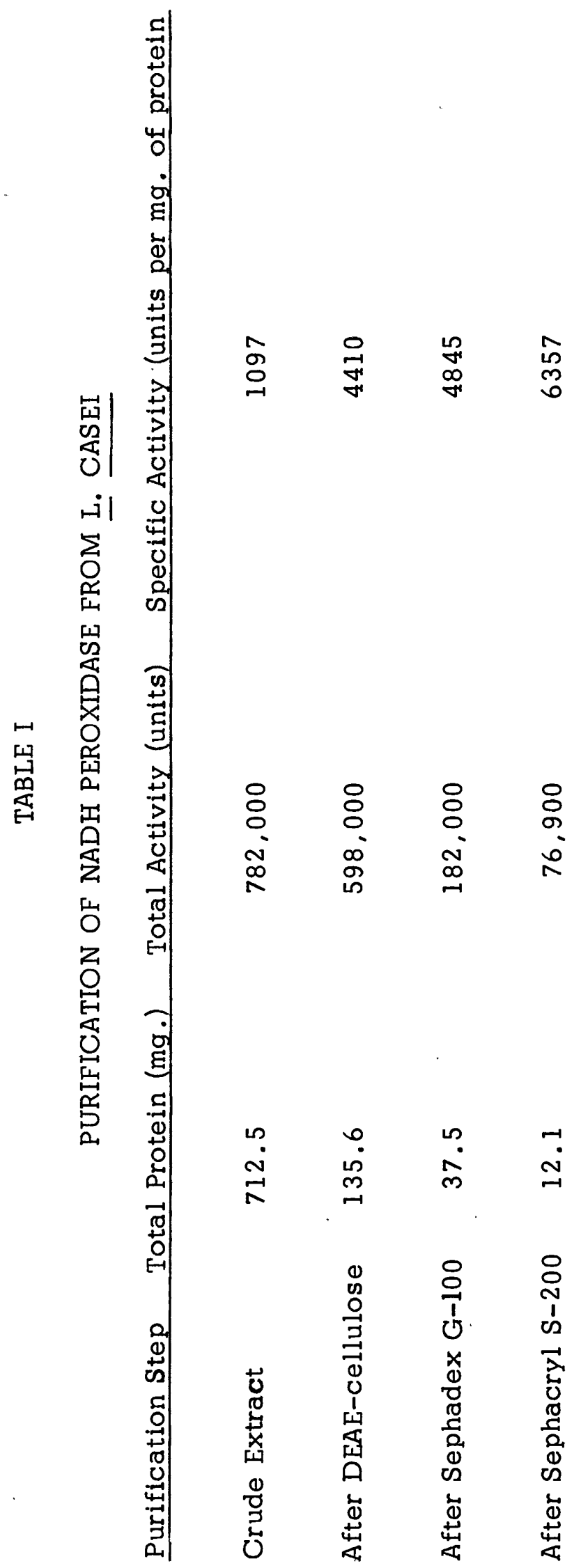




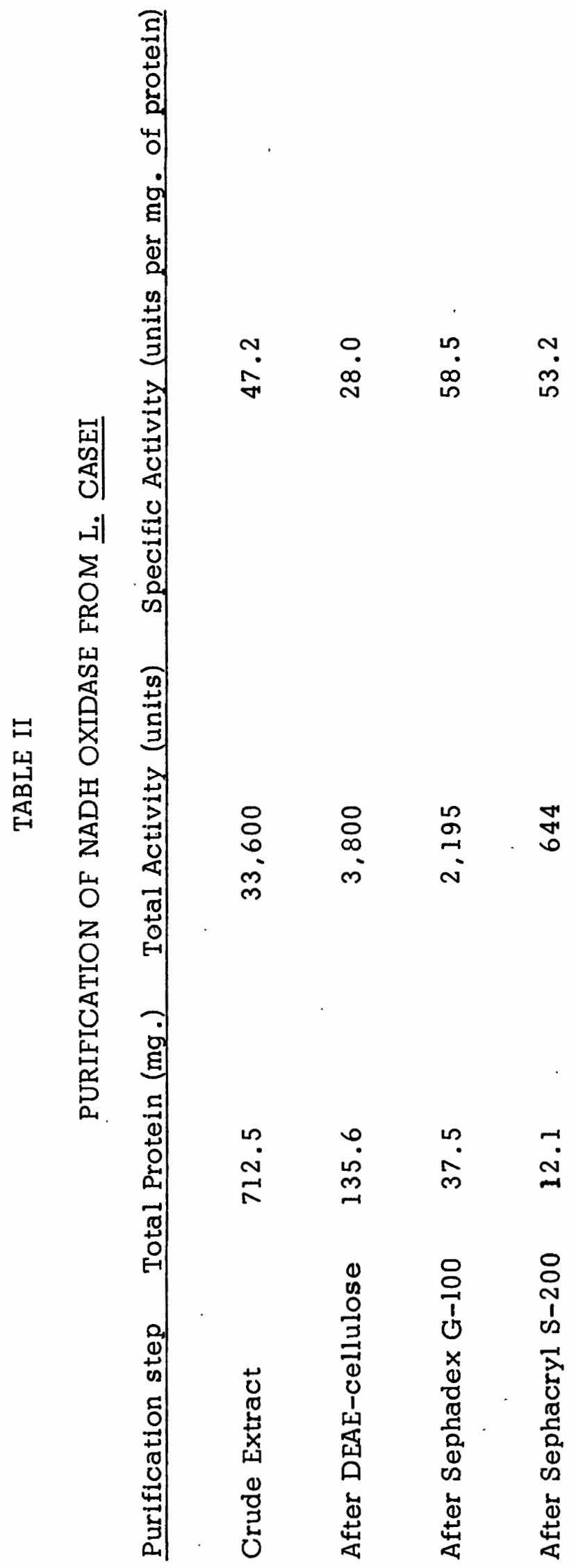




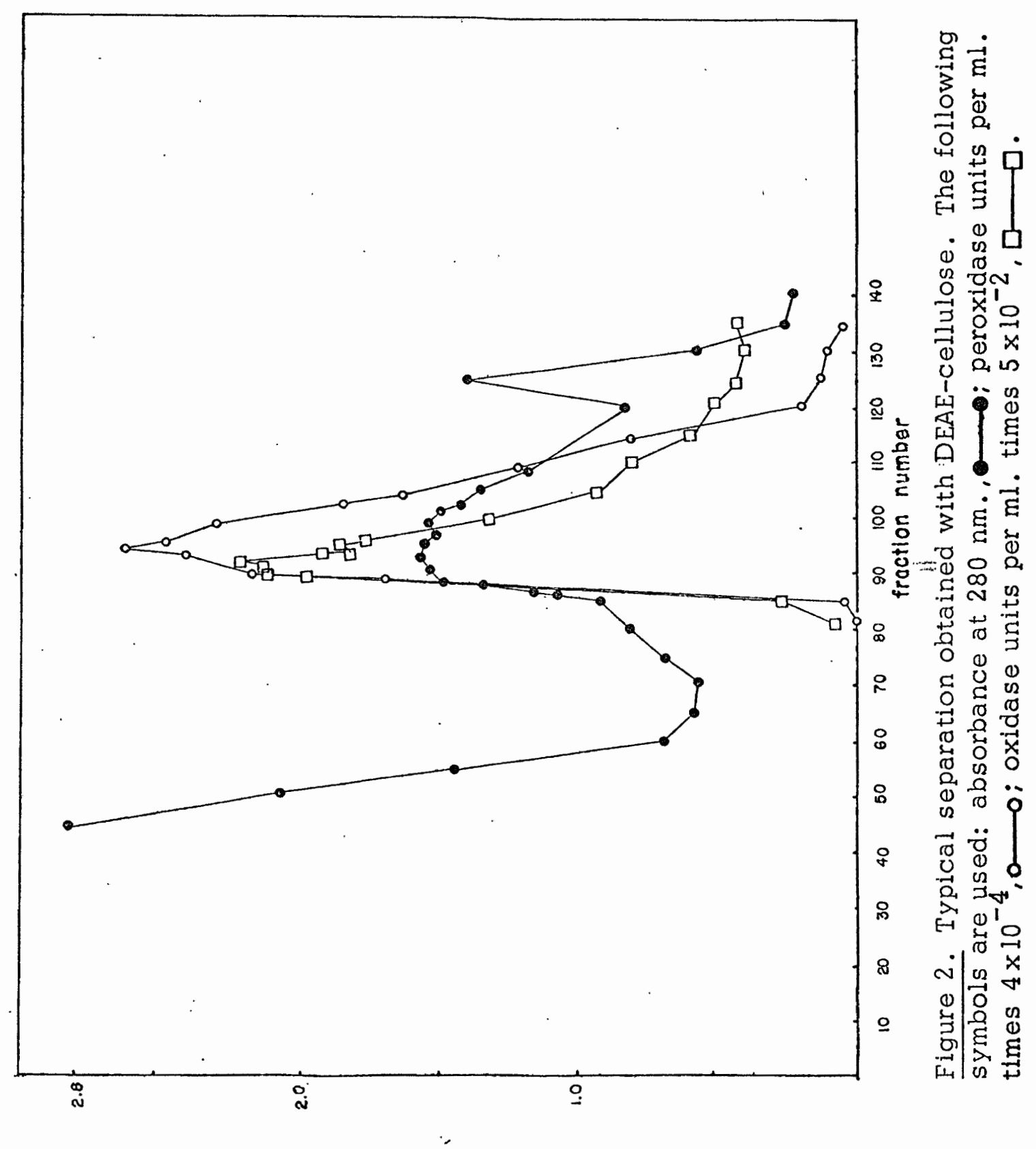




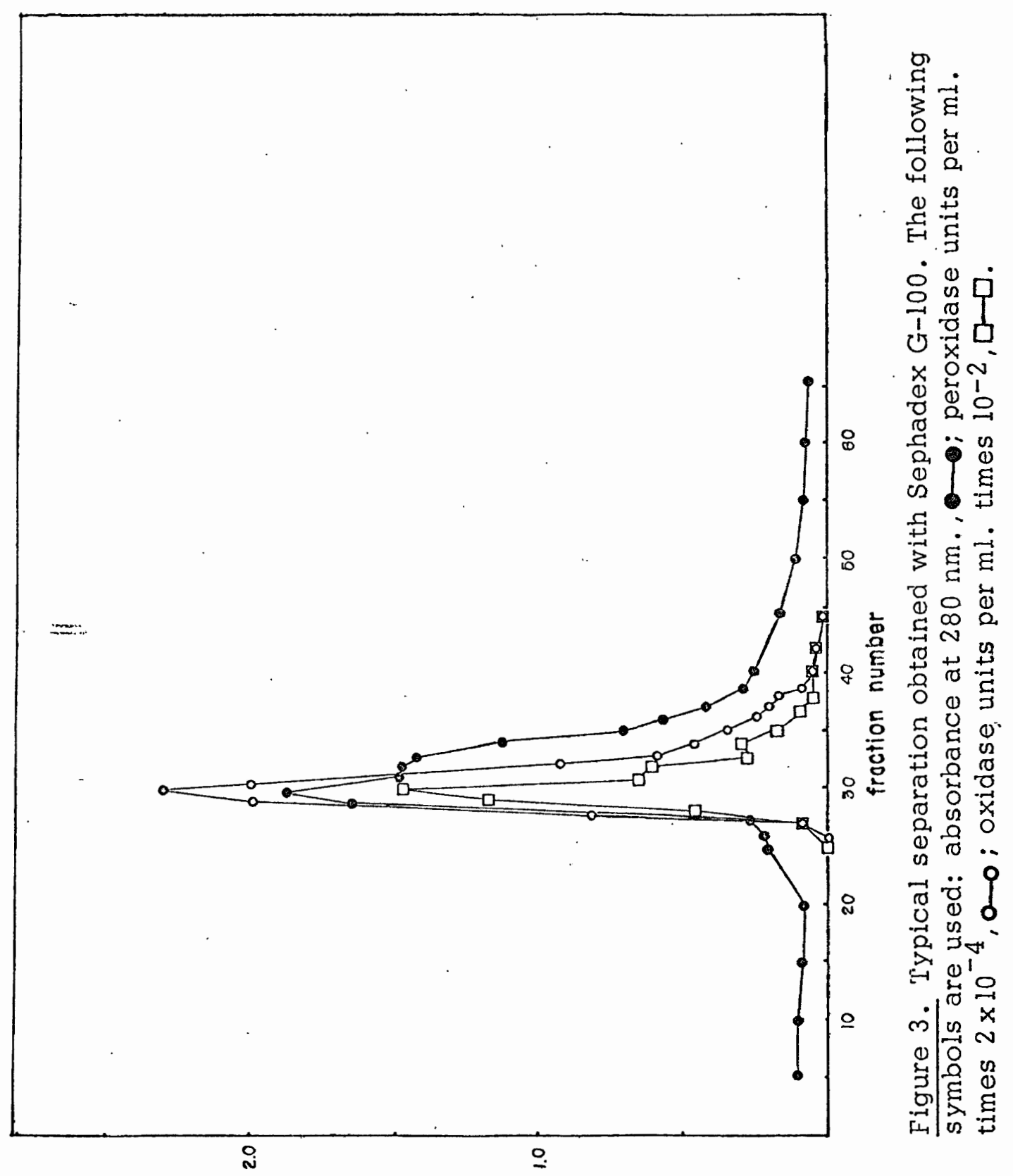




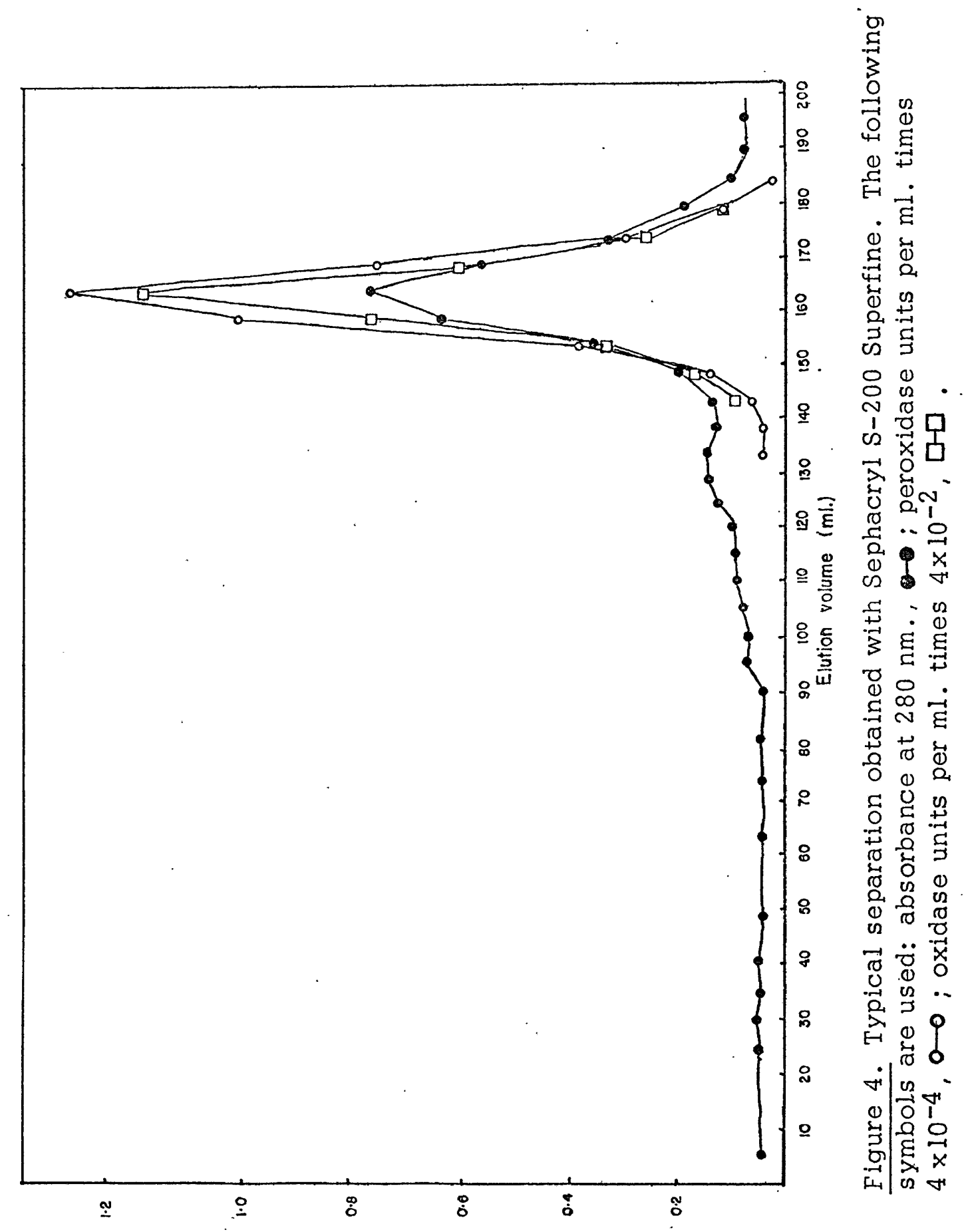




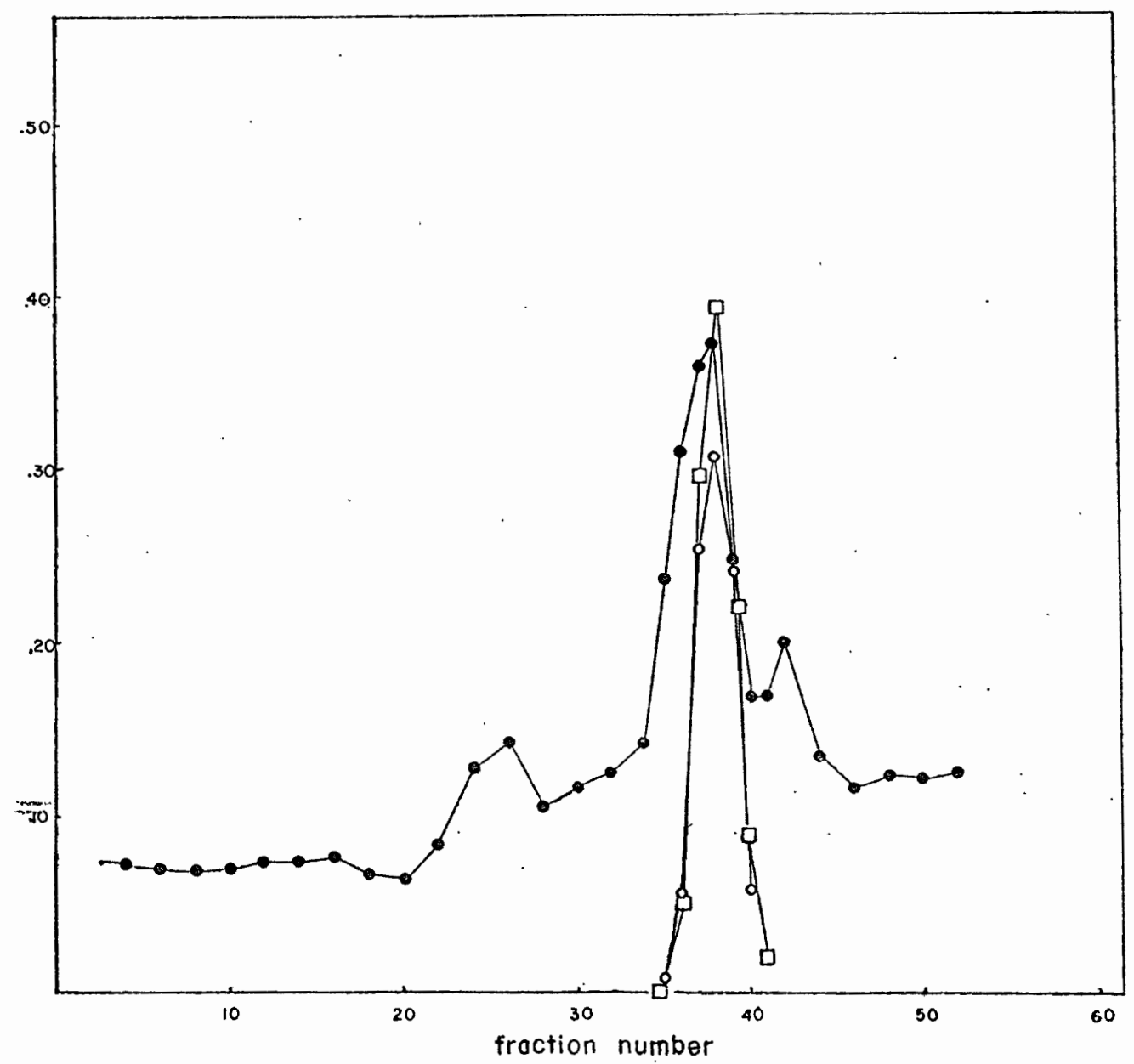

Figure 5. Typical separation obtained with Sephadex G-200. The following symbols are used: absorbance at $280 \mathrm{~nm}$., peroxidase units per ml. times $2 \times 10^{-3}, 0$ - o oxidase units per ml. times $2 \times 10^{-2}, \square \square \square$. 


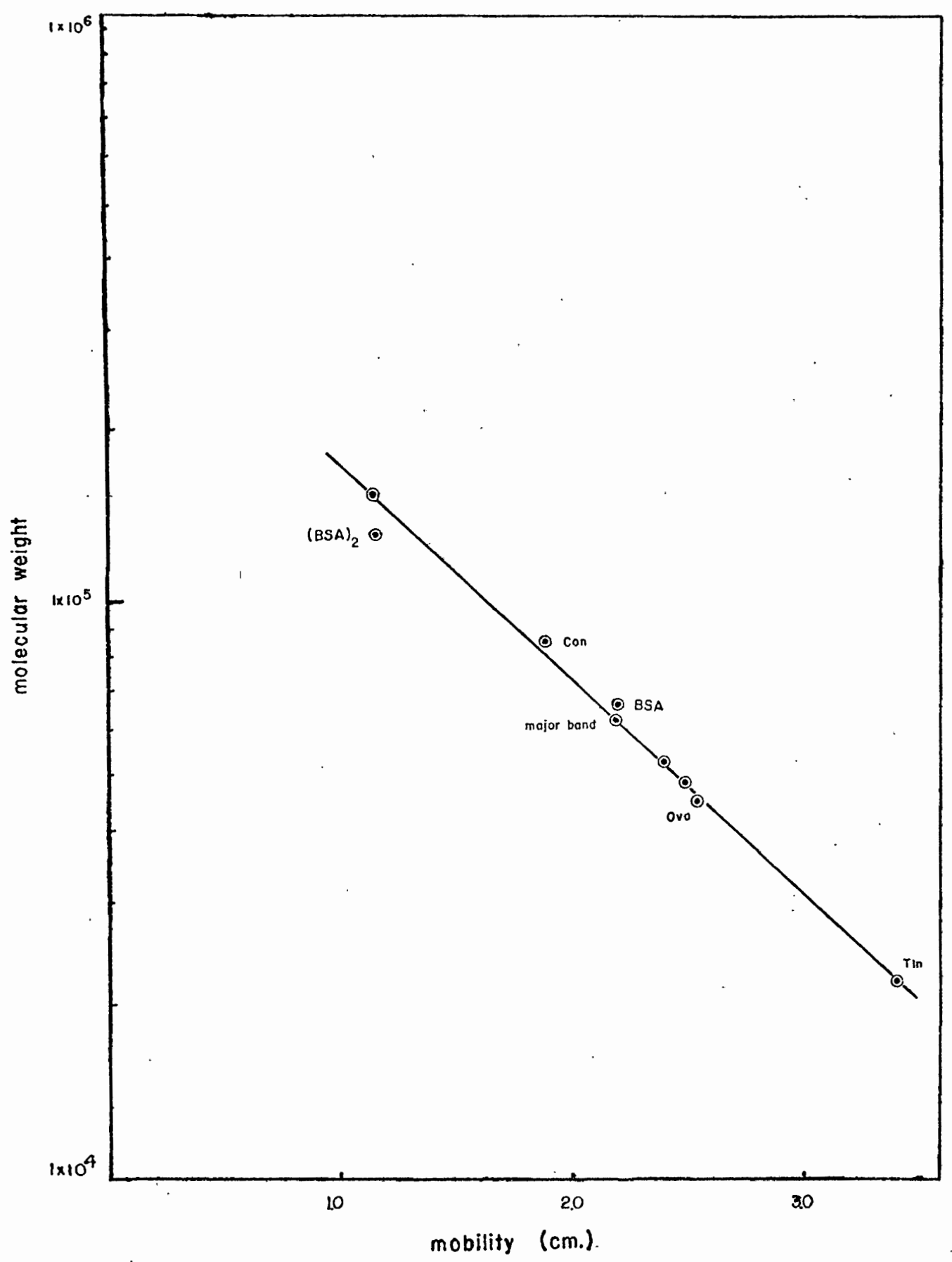

Figure 6. Determination of subunit molecular weight by SDSpolyacrylamide gel electrophoresis. Standard proteins used were bovine serum albumin (BSA), 66,000; BSA dimer ([BSA $\left.]_{2}\right)$, 155,000 ; conalbumin (Con), 85,000; ovalbumin (Ova), 45,000; trypsin inhibitor (TIn), 22,000. Unlabeled points are trace bands which did not appear after final purification. The molecular weight determined for the major band is 61,000 . 


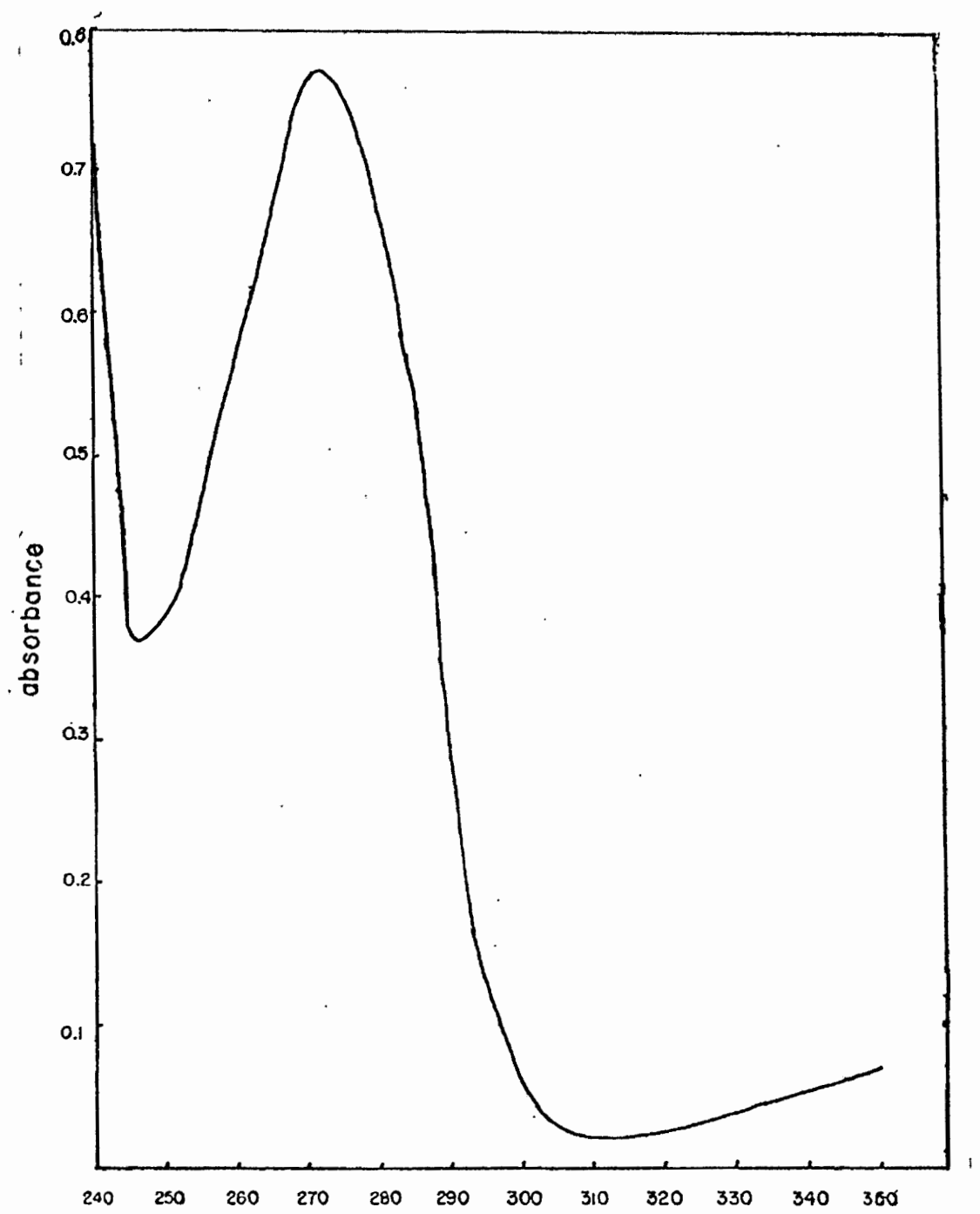

Figure 7. Ultraviolet light absorbance spectrum of enzyme in peak fraction after the final purification step. Protein concentration is $0.70 \mathrm{mg}$. per $\mathrm{ml}$. Wavelengths are shown in $\mathrm{nm}$. 


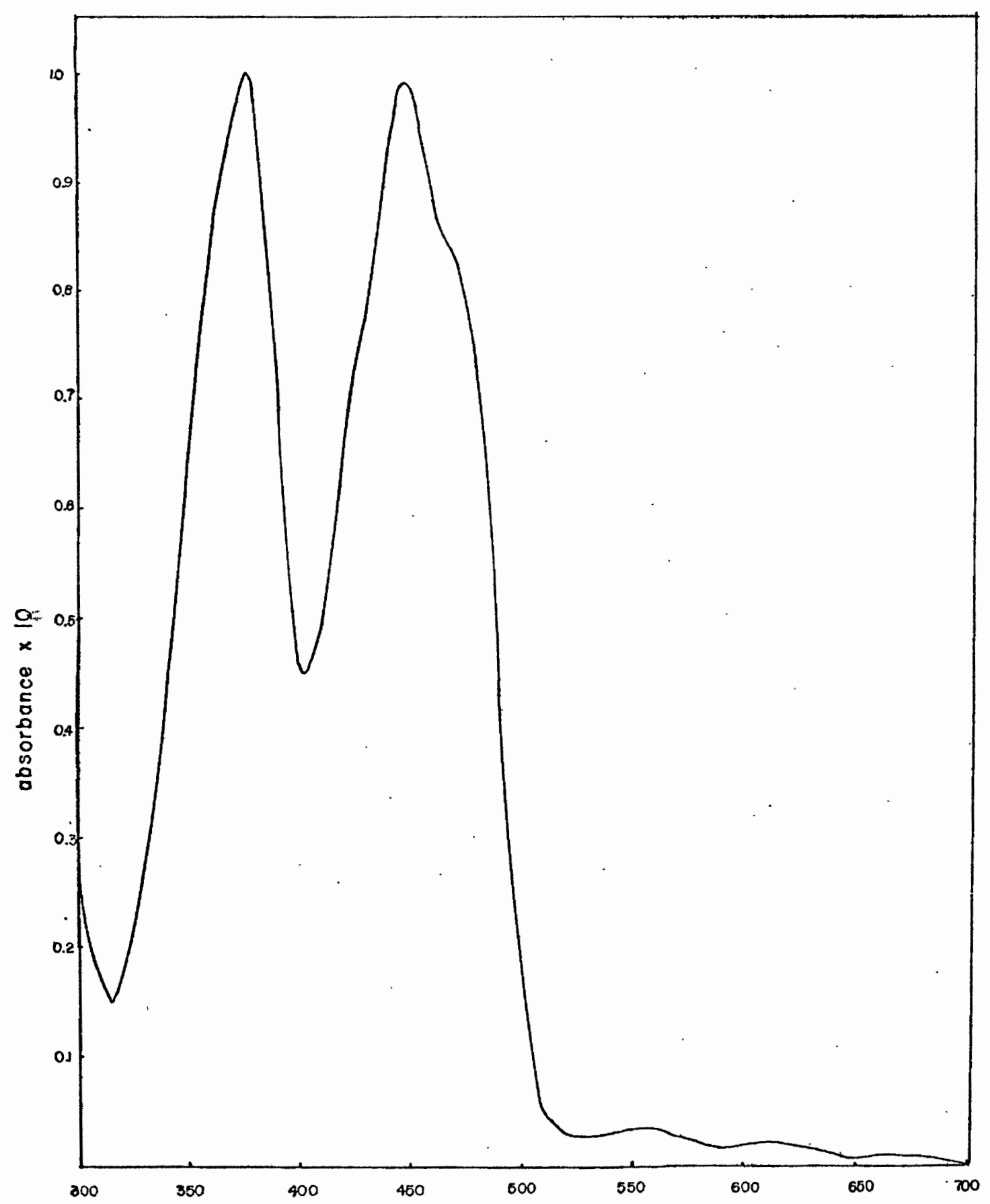

Figure 8. Visible light spectrum of enzyme in peak fraction after final purification step. Protein concentration is $0.70 \mathrm{mg}$. per $\mathrm{ml}$. Wavelengths are shown in $\mathrm{nm}$. 


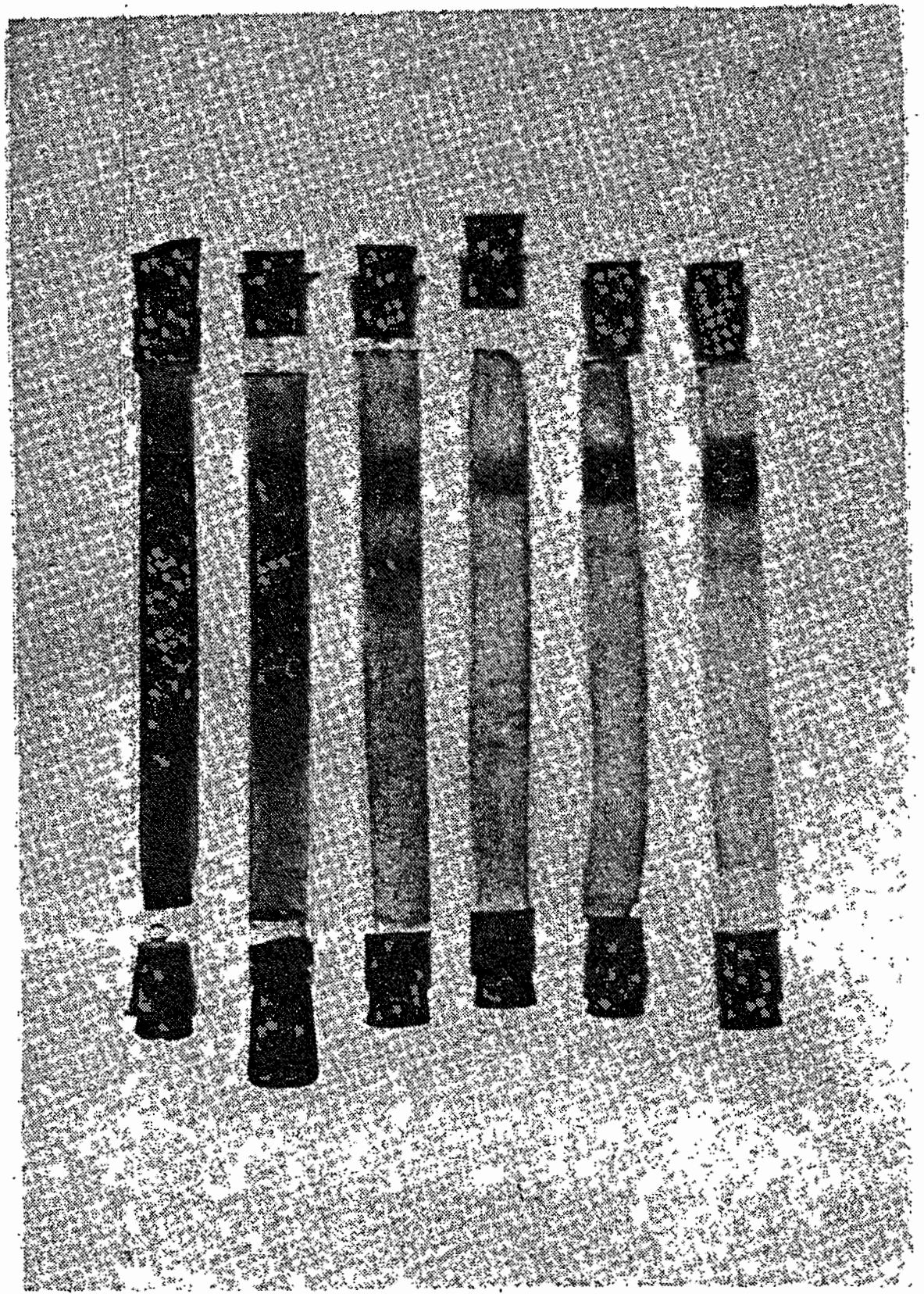

Figure 9. Five per cent polyacrylamide disc gel electrophores is. Tubes shown are, from left: breakate, $285 \mu g_{. ;}$breakate, $57 \mu \mathrm{g} . ;$ fractions pooled after DEAEcellulose chromatography, $12 \mu \mathrm{g} . ;$ fractions pooled after Sephadex G-100 gel filtration, diluted $1-100$, $0.75 \mu \mathrm{g} . ;$ peak fraction after Sephacryl S-200 superfine gel filtration, $35 \mu \mathrm{g}$. (two tubes). 

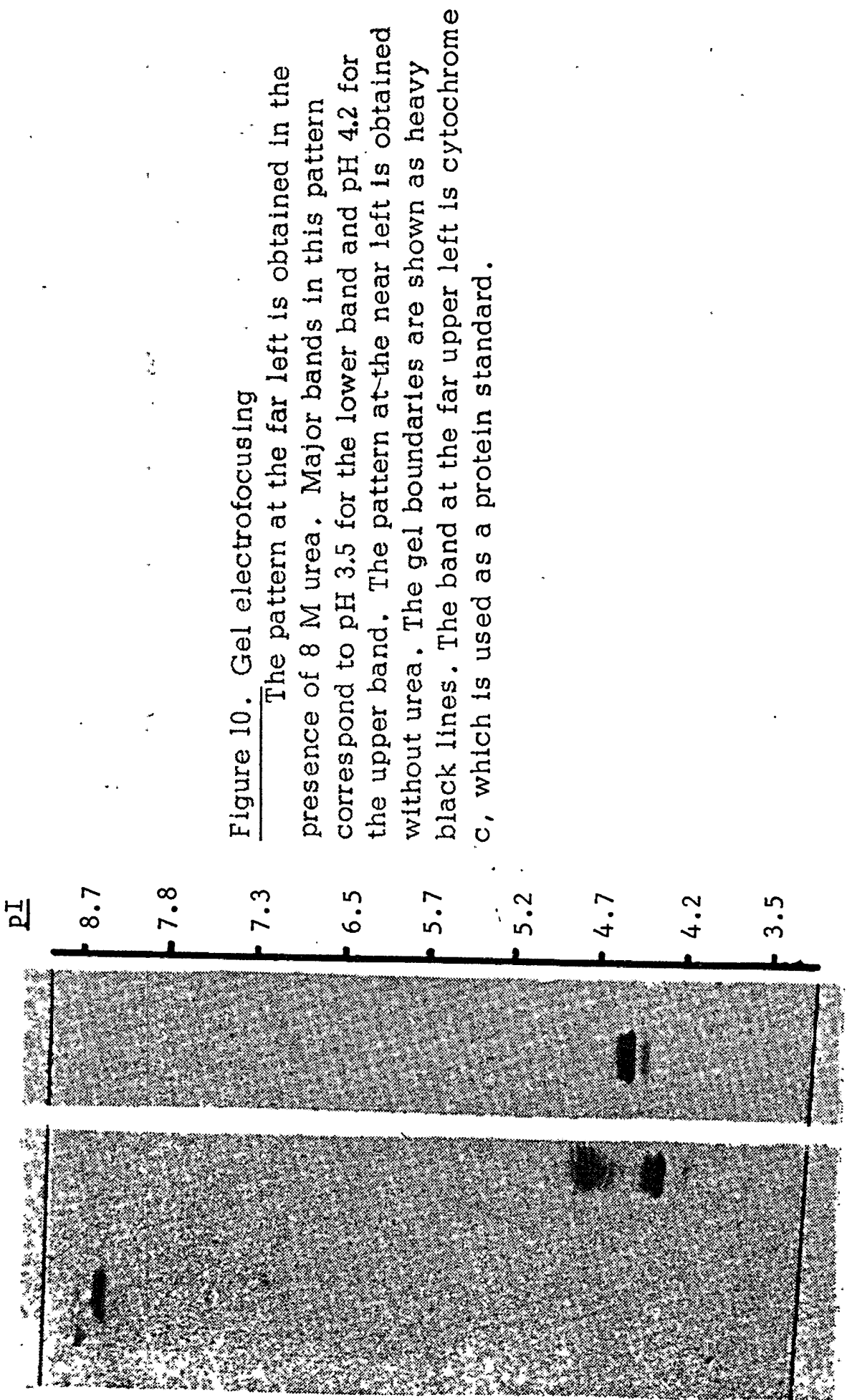


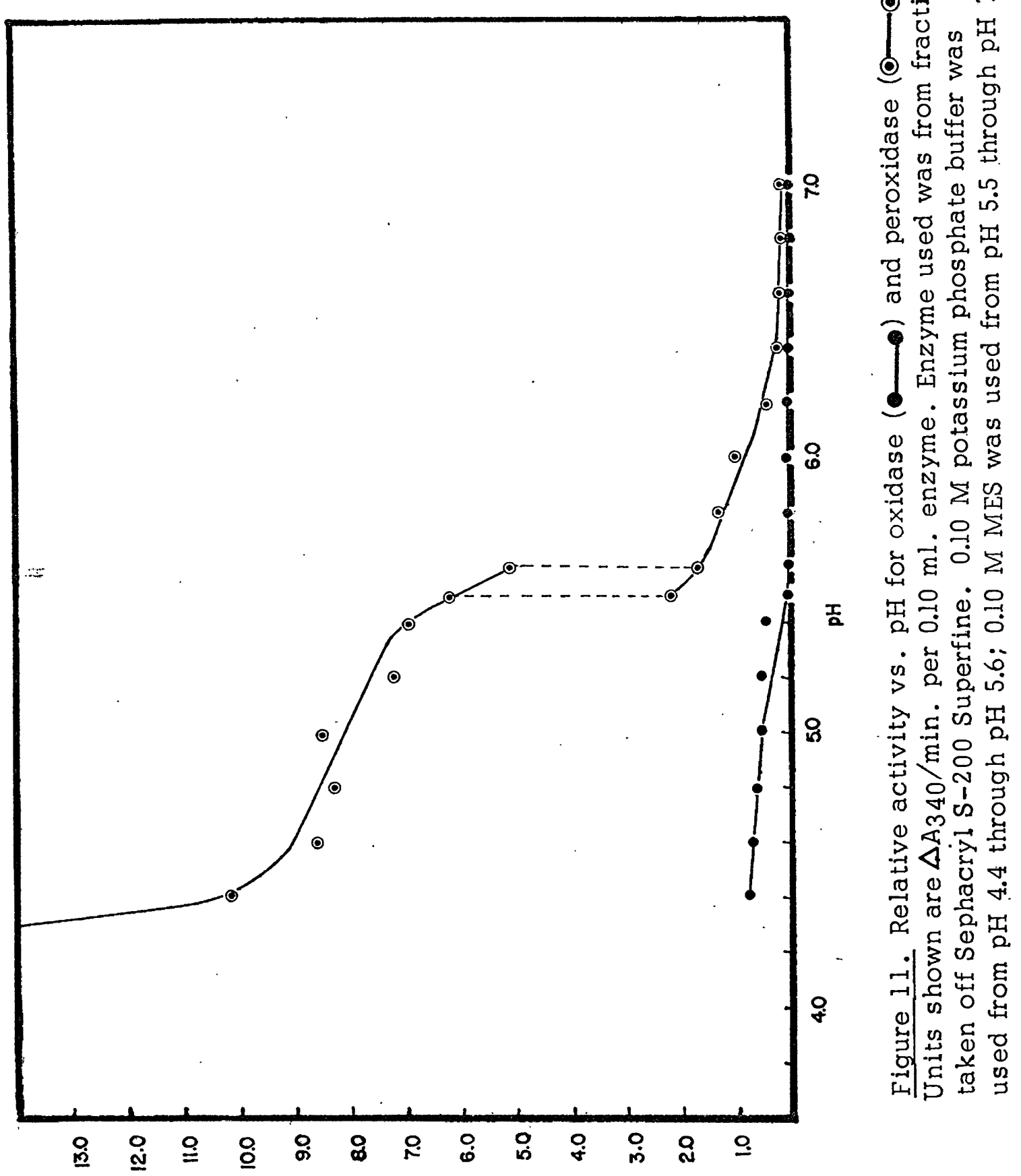




\section{REFERENCES}

1. M.I. Dolin, "The Oxidation and Peroxidation of $\mathrm{DPNH}_{2}$ in Extracts of Streptococcus faecalis, 10Cl," Arch. Biochem. Biophys., 46, 483 (1953).

2. Boehringer-Mannheim Biochemicals, Indianapolis, Product Highlights, April, 1977.

3. M. I. Dolin, "Cytochrome-Independent Electron Transport Enzymes of Bacteria" in I.C. Gunsalis and R.Y. Stanier, Eds.. The Bacteria, Chapter 10, Volume II, Academic Press, New York (1961).

4. C.F. Strittmatter, "flavin-linked Oxidative Enzymes of Lactobacillus casei, "I. Biol. Chem. 234,2794 (October 1959).

5. G.A. Walker and G.L. Kilgour, "Pyridine Nucleotide Oxidizing Enzymes of Lactobacillus casei, I. Diaphorase," Arch. Biochem. Biophys., 111, 529 (1965).

6. G.A. Walker and G.L. Kilgour, "Pyridine Nucleotide Oxidizing enzymes of Lactobacillus casei, II. Oxidase and Peroxidase, " Arch. Biochem. Biophys., 111, 534 (1965).

$=7$. G.A. Walker, The Oxidation of Reduced Nicotinamide Adenine Nucleotide by Enzymes from Lactobacillus casei, Thesis for the Degree of Ph.D., Michigan State University (1963).

8. F.M. Huennekens, R.E. Basford, and B.W. Gabrio, "An Oxidase for Reduced Diphosphopyridine Nucleotide," I. Biol. Chem., 213,951 (1955) .

9. O.H. Lowry, N.J. Rosebrough, A.L. Farr, R.J. Randall, "Protein Measurement with the Folin Phenol Reagent, " I. Biol. Chem., 193,265 (1951).

10. S.R. Himmelhoch, "Chromatography of Proteins on Ion Exchange Adsorbents," in W. B. Jakoby, Ed. , Methods in Enzymology, 22, 273, Academic Press, New York (1971).

11. Pharmacia Fine Chemicals, Piscataway, N.J., Sephadex Gel Filtration in Theory and Practice (June 1972).

12. Pharmacia Fine Chemicals, Piscataway, N.J., Sephacryl S-200 Superfine for High Performance Gel Filtration (June 1976).

13. H. Detterman, Gel Chromatography, Springer-Verlag, New York (1968), p. 82 .

14. M.I. Dolin, "The Streptococcus faecalis Oxidases for Reduced Diphosphopyridine Nucleotide," I. Biol. Chem., 225,557 (1957). 
15. M.I. Dolin, "Reduced Diphosphopyridine Nucleotide Peroxidase," I. Biol. Chem., 250,310 (1975). 